Bryn Mawr College

Scholarship, Research, and Creative Work at Bryn Mawr College

Classical and Near Eastern Archaeology Faculty

Research and Scholarship

Classical and Near Eastern Archaeology

1966

\title{
Greek Kouroi and Egyptian Methods
}

Brunilde S. Ridgway

Bryn Mawr College, bridgway@brynmawr.edu

Let us know how access to this document benefits you.

Follow this and additional works at: http://repository.brynmawr.edu/arch_pubs

Part of the Classical Archaeology and Art History Commons, and the History of Art, Architecture, and Archaeology Commons

\section{Custom Citation}

Ridgway, Brunilde S. 1966. Greek Kouroi and Egyptian Methods. American Journal of Archaeology 70:68-70.

This paper is posted at Scholarship, Research, and Creative Work at Bryn Mawr College. http://repository.brynmawr.edu/arch_pubs/38

For more information, please contact repository@brynmawr.edu. 
These four examples of prayers, all using forms of the verb déxoral, leave no doubt as to the good intentions of the persons offering them, and strongly indicate that the Morgantina tabellae, which employ very similar wording, were offered under similar circumstances and with similar intentions, and therefore are not tabellae defixionum. Although the Morgantina

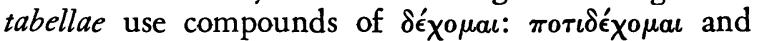
$\pi a \rho a \delta \epsilon_{\chi} \neq \mu a \iota$, neither of the compounds is far removed in meaning from $\delta \epsilon_{\chi \circ} \mu \mu \iota$ and certainly has no pejorative sense.

It should be noted that whereas the prayers mentioned supra employ imperative forms of the verb, the Morgantina tabellae in three instances use the second person future. ${ }^{12}$ The futures are readily understandable as alternates for the imperative. ${ }^{13}$

Only one of the Morgantina tabellae seems definitely to have been intended as a curse:

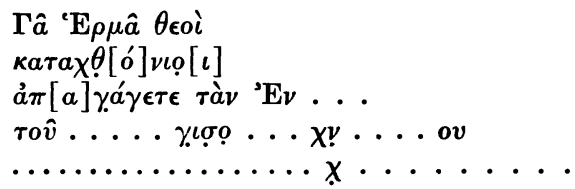

It is important to note the change of verb here. The normal mild verb has been abandoned in favor of one which is strong and unambiguous. Otherwise, the tablet seems to follow a formula characteristic of the Morgantina tabellae.

It is not disturbing to find this one tabella defixionis mixed in with pious prayers which are of an entirely different purpose and tone. Nor is it alarming to find pious prayers written on lead and burnt, in the manner of tabellae defixionum. Both pious prayers and curses are directed to the same underworld gods, and therefore their form and place of deposit would be expected to be the same. The only difference between a pious prayer and a curse is the intent of the person offering it, and the intent can only be discovered from the wording of the prayer.

NED NABERS

THE UNIVERSITY OF KANSAS

\section{GREEK KOUROI AND EGYPTIAN METHODS}

In the Proceedings of the American Philosophical Society 107:1 (1963) 60-81, Rudolf Anthes published a paper on "Affinity and Difference between Egyptian and Greek Sculpture and Thought in the Seventh and Sixth Centuries в.c." With remarkable modesty he stated at once ${ }^{1}$ that he was "transgressing his limits" in making comments on the Greek side of the picture, and invited the reader to react accordingly. These

12 Of the remaining three legible, or partially legible, tablets, two employ the aorist imperative, and the verb is completely lost on the third tablet.

13 Cf. J. Hadley and F. Allen, Greek Grammar (New York 1890) \#844: "The second person of the future is used as a softened form of the command. . . ."

${ }^{1}$ Anthes, op.cit. 60. notes are an answer to the invitation, and need hardly be prefaced by the warning that they claim no authority on the Egyptian side of the question: they represent at best only partial answers and suggestions to some of the many interesting points raised by Professor Anthes.

As I understand the paper, Anthes tries to establish that the archaic Greeks were indebted to the Egyptians only in an indirect and relative way. And as Egyptian thought was alien to the Greek mind and had to be rejected or adapted, so their intellectual approach to sculpture was equally unsatisfactory to the "realistic" Ionians, who adopted only Egyptian manual techniques and used Egyptian art "as a background rather than an example for their own work." In confirmation of this point of view Anthes quotes the passage of Diodorus Siculus (1.98.5-9) in which it is told how Telekles and Theodoros made a statue "in the Egyptian manner," each fashioning only half of the figure, but in such a precise way that the two parts joined exactly, though one had been executed in Samos and the other in Ephesos.

This passage, with its mention of an Egyptian division of statues into twenty-one and one-fourth parts, has long been controversial. C. H. Oldfather, in his translation of Diodorus, took it to mean that the Egyptian method of working-" practised nowhere among the Greeks"-consisted in making a statue of separate parts, or more specifically in two halves, as contrasted with the Greek approach to the statue as a whole. Yet he was aware of the difficulty of the text, and quoted Heinrich Schäfer's remarks and translation in support of his own. ${ }^{3}$

A different interpretation was given by Casson, ${ }^{4}$ who, following Kluge's explanation of the sand-casting method in bronze, ${ }^{5}$ read Diodorus' passage as a slightly confused account of the process. For this technique of making a bronze statue requires that a wooden model be carved and an impression of it in sand be taken in two halves (to permit the removal of the wood from the mold). The two sections of the mold are then joined together around a rough clay core and the statue is cast as a whole. However it is now more generally believed that the two Samian sculptors cast their bronzes by the lost-wax process, as implied by Pausanias (8.14.8).

Anthes proposes a new approach. He maintains that Diodorus' emphasis on the "non-Greek" procedure followed by Telekles and Theodoros refers not to the actual making of the statue in two halves, but to the adoption of the strict system of proportions employed by the Egyptians, which, once the unit of measure was agreed upon, allowed different sculptors to work sepa-

2 op.cit. 67.

${ }^{3}$ Loeb Classical Library (1933) 336-339; notes 3 on 336 and I on 338 . He also adds that no explanation of the twentyone and one-fourth parts had been found in any modern writer; but see infra for a recent explanation.

${ }^{4}$ The Technique of Early Greek Sculpture (Oxford I933) 155.

$5 \mathrm{~K}$. Kluge, "Die Gestaltung des Erzes in der archaischgriechischen Kunst," JdI 44 (I929) I-30. 
rately on different parts of the statue with perfect results. In this fashion, Egyptians made their statue according to a specific, though perhaps unrealistic, canon, and therefore justified Diodorus' comment that "with them the correct proportions of the statues are not fixed in accordance with the appearance (of the human body: phantasia) which presents itself to the eyes, as is done among the Greeks." 6 This explanation takes into account the results of recent studies by Iversen, ${ }^{7}$ showing that the Egyptians, in carving a statue, used a grid based on a division of the standing human figure in twenty-one and one-fourth parts. Anthes readily admits that the Greeks also used a grid of sorts, but believes that its function (as for the Egyptians of the second millennium B.c.) was as an aid to drawing identical forms on two different sides of a block. In the first millennium, when the Greeks learned their technique, he assumes instead that the Egyptians themselves employed the grid in a different fashion: as a network for locating points in the interior of the block. ${ }^{8}$

On the basis of Anthes' explanation, one would infer that the archaic Greeks did not use standard proportions. Yet Iversen has shown that exactly the same ratio went into an early Greek kouros as that based on the contemporary Egyptian grid system. ${ }^{9}$ We possess no literary reference to an established archaic canon, but it is logical to assume that one, or several, must have existed, not only on the basis of actual calculations and comparisons with Egyptian works, but also on account of the great propensity for numbers displayed by the Greeks. The fifth century в.c. surely knew "measured" statues. Polykleitos established his own canon with the Doryphoros, and even Lysippos in the fourth century, Pliny tells us, though introducing slenderer proportions, "diligentissime custodiit [symmetriam] nova intactaque ratione quadratas veterum staturas permutando" ( $\mathrm{NH} 34.65)$. Why, therefore, Diodorus' insistence that the Greeks did not use a canon of proportions but followed "phantasia"? 10 I submit that the answer to this apparent difficulty

6 Anthes' translation, based on Oldfather's text, op.cit. 66. ${ }^{7}$ Iversen, E., "The Egyptian Origin of the Archaic Greek Canon," MittKairo I5 (1957) I34-I47.

${ }^{8}$ Anthes however adds (p. 65): "the evidence is rather meager for my distinction between an earlier, figural system of guide lines in sculpture identical with the Greek archaic method, and a later mathematical system."

${ }^{9}$ Op.cit. (supra, n. 7) I34-135. He does not distinguish between an earlier and a later, different, use of the grid, but rather between an earlier division of the human figure into eighteen squares, from the sole of the feet to the hairline of the forehead, in use from about the third to the twenty-sixth dynasty, and a later division into twenty-one squares, from the sole of the feet to a line through the eyes, employed from the twenty-sixth dynasty onward. But see also K. Levin, "The Male Figure in Egyptian and Greek Sculpture," $A] A 68$ (1964) 13-28, esp. I 8-19, where it is suggested that "any archaic Greek canon would probably have proceeded in much the way the Doric order proceeded in its problem of the corner metope and triglyph: by continual reworkings of problems of ratio, relations of parts, finally developing into the famous Greek can be found in that same passage of Pliny quoted above. It continues in fact: "(Lysippus) vulgoque dicebat $\mathrm{ab}$ illis factos quales essent homines, a se quales viderentur esse."-"and he often said that the difference between himself and them (the older artists) was that they represented men as they were, and he as they appeared to be."11 These Latin words, difficult to interpret as they may be, seem to me the direct echo

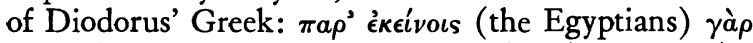

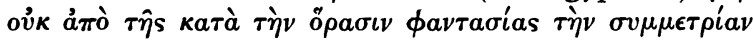

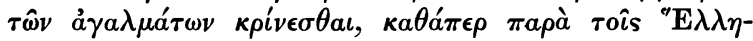
$\sigma \iota v .{ }^{12}$

Pliny's statements ultimately derive from the works of Xenokrates of Sikyon and Antigonos of Karystos, his ancient sources on art; Diodorus is generally held to have drawn primarily upon Hekataios of Abdera. Thus both authors, Pliny, who lived under the Flavians in the first century A.D., and Diodorus, who wrote between 56 and 36 B.c., go back to writers of the early Hellenistic period. Accurate as they may have been in paraphrasing their sources, the point of view they reflect is inevitably that of the third and second centuries B.C., not that of the archaic or classical periods. Pliny, more systematic in his investigation of ancient art, knows about the enforcement of some canon throughout Greek sculpture. Diodorus, who touches upon art only incidentally, bases his comments on the practices of his own time, which tended to reproduce natural, rather than ideal, forms and proportions.

Diodorus' passage should therefore be understood to mean that the sixth-century masters Telekles and Theodoros made their statues according to the Egyptian canon of proportions; his remarks about the lack of such standard measurements among the Greeks should be taken to refer, not to archaic, but to Hellenistic contemporary procedures.

We can thus understand why, in Diodorus' description, the finished product of Telekles and Theodoros, though allegedly made in a non-Greek fashion, seems to correspond closely to our definition of an archaic male statue, "for the most part similar to those of

canon of Polykleitos."

${ }^{10}$ One could, of course, maintain that Diodorus says nothing of the sort, and that his "Egyptian method of working" refers exclusively to making a statue in two halves. But my comments are based on the assumption that Anthes is correct in his interpretation.

11 Trans. Jex-Blake. My italics.

12 Prof. Mabel Lang reminds me that the Latin has a nearer echo in a passage of Aristotle ("just as Sophocles said that he portrayed people as they ought to be and Euripides portrayed them as they are," Poetics 25.II; trans. W. Hamilton Fyfe, Loeb Classical Library). She suggests that a balanced statement of this kind is just a rhetorical device meant to indicate difference. The passage in Diodorus might be a similar formula, with the balancing clause only implied, and therefore might merely state that Greek methods are different from the Egyptians; in this case one should not speculate on its literal meaning. On the other hand, it is significant that also in Aristotle the difference consists in idealization versus realism, and would correspond to a definition of classical versus Hellenistic sculpture. 
Egypt, as having the arms stretched stiffly down the sides and the legs separated in a stride." ${ }^{13}$ Anthes points out that the similarity between a kouros and an Egyptian male figure is only superficial. In particular, the Egyptian posture, with the body in a line with the weight leg and the forward leg at a considerable distance from the other, is seen as quite different from the even balancing of the body on both legs of the kouroi. I venture to suggest that a technical reason may lie behind this difference. The Egyptian usually approached his work with full understanding of the limitations of stone, and therefore did not endeavor to carve away the "screen" between the outstretched left leg and the body, nor the rear surface of the block, against which the statue stood. In consequence his figures adhered closely to this background, thus tilting their balance backward; likewise, because of the relief-like carving of the forward leg, a bold extension of the limb was possible. On the contrary, the Greek sculptor, conceiving his statue as fully in the round, removed the back pillar and tried to free the limbs of his figure from any connecting "membrane" of stone. As a result his kouroi, unable to lean backward against a non-existing support, had to balance their weight on their two legs. Similarly their left legs, carved entirely in the round, could not be stretched too far forward, to prevent breakage. The final result of these modifications is that the kouroi have a more natural aspect than the Egyptian statues, fully in keeping with the Greek propensity for anatomical analysis and imitation of human forms; and it may well be that these solutions to material difficulties were found because of such propensity; but Anthes tends to stress the latter element, while I feel that both factors-the mental approach and the technical requirementsplayed an equally important role.

In summary: I believe that Anthes' new interpretation of Diodorus' passage is correct, and that the Greek writer, when stressing the dissimilarity between the Egyptian and the Greek methods of working, is actually referring to a difference in approaches: an Egyptian, intellectual approach, based on strict and artificial measurements, as against a Greek, more naturalistic rendering of a human figure according to its appearance in real life. But while Anthes maintains that Diodorus' remark is correct and that a Greek kouros is basically different from an Egyptian male figure, I believe that whatever difference is apparent stems from technical strictures rather than intentional modifications. The contradiction thus implicit in Diodorus' words might be explained by assuming that he is judging Greek sculpture as it was made, not in the

13 Diodorus, loc.cit.; Anthes, op.cit. 66.

14 See, on this subject, K. Levin, op.cit. (supra, n. 9) 19-2I.

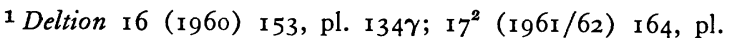
I $77 \gamma$. The former reference identifies the figure as a warrior. The latter volume, which has the better photograph, correctly identifies the figure as a man carrying a staff.

2 P. Girard, "Inscriptions archaiques de la Locride Opuntienne," $B C H 2$ (I 878 ) 588 no. 7 , pl. xxvi, no. 20.
}

archaic, but in the Hellenistic period, when it had indeed acquired great naturalism, thus losing its initial resemblance to formal Egyptian art.

I am aware that I have omitted discussion of some of Anthes' points, such as the difference in the general bodily structure between Egyptian and Greek figures. ${ }^{14}$ And it is, of course, true that what matters in this context is not what the Greeks borrowed from the Egyptians, but how they interpreted and transformed it, and why. But I hope that my comments may prompt a reconsideration of Diodorus' intriguing passage and of the whole complex question.

$$
\text { Brunilde Sismondo Ridgway }
$$

BRYN MAWR COLLEGE

\section{A BIBLIOGRAPHICAL NOTE}

In the Chronika of the 1960 and 1961/62 volumes of the Archaiologikon Deltion is illustrated the upper part of an archaic grave stele found in the wall of the monastery of Hagios Georgios near Malesina in Opuntian Lokris and now located in the Thebes Museum. ${ }^{1}$ The purpose of this note is to add bibliographical material which does not appear in either of the Deltion articles. The stele depicts a bearded man facing toward the proper left and holding a staff in his right hand. Part of the crowning molding remains above the sculptured panel. The lower break occurs slightly below the waist of the figure and a large round hole appears beneath the right hand. The figure wears a tightly wrapped mantle which extends from under the right arm, across the torso, and over the left shoulder, completely concealing the left arm. A portion of the drapery falls from behind the right shoulder.

This stele was first published by P. Girard in 1878 ,

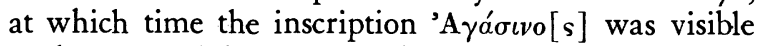
in the upper right corner. ${ }^{2}$ The work was subsequently discussed in more detail by G. Körte in 1878 and again in $1879 .^{3}$ The latter discussion includes a line drawing which, in addition to the inscription, indicates the existence of painted molding decoration. Recently the stele has been cited in connection with its sculpture by Professor Akurgal, and in connection with its inscription by Miss Jeffery. ${ }^{4}$ From the Deltion photographs it appears that the inscription might no longer be visible, and no mention of it is made in the accompanying text. We may conclude, however, that this is the stele of Agasinos.

\section{Elizabeth T. Wakeley}

\section{UNIVERSITY OF PENNSYLVANIA}

${ }^{3}$ G. Körte, "Die Antiken Sculpturen aus Boeotien," $A M 3$ (1878) 313, no. 7; "Bemerkungen zu den Antiken Sculpturen aus Boeotien," $A M 4$ (1879) 268ff, pl. xIv, 2.

4 E. Akurgal, Zwei Grabstelen Vorklassischer Zeit aus Sinope (I I I Winckelmannsprogramm der Archäologischen Gesellschaft zu Berlin, Berlin 1955) 27 no. 21 dated 480-470; L. H. Jeffery, The Local Scripts of Archaic Greece (Oxford 1961) 107, I 08 no. I2. 